\title{
MENINGKATKAN HASIL BELAJAR KOGNITIF PRODUK SISWA PADA MATERI BIOLOGI CIRI-CIRI MAKHLUK HIDUP KELAS VII SMPN 3 BANJARBARU
}

\author{
Eva Sylviaty ${ }^{1}$, Yulianti Hidayah ${ }^{2}$ \& Almira Ulimaz ${ }^{3}$
}
1. Program Studi Pendidikan Biologi STKIP PGRI Banjarmasin evasylviaty@gmail.com (087815704053)

2. Program Studi Pendidikan Biologi STKIP PGRI Banjarmasin yuliantihidayah79@gmail.com (085345617823)

3. Program Studi Pendidikan Biologi STKIP PGRI Banjarmasin almiraulimaz2521988@gmail.com (081351351988)

\begin{abstract}
ABSTRAK
Ilmu Pengetahuan Alam atau IPA merupakan suatu bidang ilmu yang banyak berhubungan dengan manusia dan gejala-gejala alam yang ada disekitarnya. Pendidikan IPA adalah salah satu usaha sadar yang bertujuan untuk mengembangkan kualitas manusia sebagai seseorang yang hidup di lingkungan sebagai makhluk sosial maupun makhluk personal. Sebagai usaha kegiatan yang sadar akan tujuannya, maka dalam pelaksanaannya berada dalam suatu proses yang berkesinambungan di setiap jenis dan jenjang pendidikan termasuk sekolah menengah pertama. Hal ini dimaksudkan agar pembelajaran menjadi lebih bermakna bagi siswa yang menjadi peserta didiknya. Pendidikan biologi diharapkan dapat menjadi wahana bagi peserta didik untuk mempelajari diri sendiri dan alam sekitar, serta prospek pengembangan lebih lanjut dalam menerapkannya di dalam kehidupan sehari-hari. Berdasarkan hasil observasi dan informasi dari guru IPA kelas VII SMPN 3 Banjarbaru, pada semester genap belum tercapai nilai KKM yang ditetapkan sekolah dengan nilai 71. Diantara upaya guru yang dapat dilakukan adalah dengan menerapkan model pembelajaran inkuiri terbimbing. Tujuan penelitian ini untuk meningkatkan hasil belajar kognitif produk siswa kelas VII SMPN 3 Banjarbaru terhadap pembelajaran IPA Biologi materi ciri-ciri makhluk hidup dengan menggunakan model pembelajaran inkuiri terbimbing. Metode penelitian yang digunakan adalah metode deskriptif. Subjek penelitian ini adalah siswa dan siswi kelas VII SMPN 3 Banjarbaru Kota Banjarbaru Tahun Pelajaran 2015/2016 dengan jumlah total siswa sebanyak 25 orang. Jenis penelitian ini adalah penelitian tindakan kelas atau PTK dan penelitian ini berlangsung selama dua siklus. Setiap siklus terdiri dari dua kali pertemuan. Data hasil belajar kognitif produk siswa diperoleh melalui pemberian pretes dan postes. Analisis data melalui lembar analisis kuantitatif dan kualitatif dengan menggunakan teknik persentase (\%). Hasil penelitian menunjukkan siklus I pertemuan ke 1 rata-rata nilai postes adalah 74,40 dengan ketuntasan klasikal sebesar 76,00\%, pada pertemuan ke 2 meningkat menjadi 79,20 dengan ketuntasan klasikal sebesar $84,00 \%$. Siklus II pertemuan 1 ke 1 rata-rata nilai postes adalah 79,60 dengan ketuntasan klasikal sebesar $84,00 \%$, pada pertemuan ke 2 menjadi 82,00 dengan ketuntasan klasikal sebesar 92,00\%.
\end{abstract}

Kata Kunci: hasil belajar, ciri-ciri makhluk hidup, inkuiri terbimbing. 


\section{PENDAHULUAN}

Pendidikan saat ini sepertinya hanya menuntut siswa untuk menguasai kumpulan konsep pengetahuan berupa fakta dan konsep, tetapi cukup kurang dalam hal proses melakukan dan menemukan konsep itu sendiri. Padahal sudah menjadi kesepakatan umum bersama bahwa seyogyanya pada anak usia sekolah akan dapat mencerna suatu konsep dengan baik, apabila mereka belajar sesuatu secara nyata/kongkrit dan kontekstual. Mereka akan lebih mudah memahami dari apa yang dipelajarinya jika terlibat langsung dalam aktivitas pembelajaran itu sendiri. Oleh karena itu, proses pembelajaran Biologi di SMP sebaiknya ditekankan kepada pemberian pengalaman langsung pada siswa.

Pembelajaran di sekolah tidak lepas dari pentingnya peran seorang pendidik atau guru. Guru yang masih menggunakan metode konvensional atau ceramah saat mengajar merupakan pekerjaan rumah (PR) besar bersama untuk dapat berubah menjadi metode yang lebih memprioritaskan kepada keaktifan siswa saat KBM berlangsung. Hal ini tentu bertujuan untuk meningkatkan kinerja dan kualitas pembelajaran itu sendiri dalam rangka meningkatkan keterampilan mengajar, yaitu mengubah sistem pembelajaran konvensional menjadi sistem pembelajaran dengan menggunakan model pembelajaran yang sesuai. Hal ini dimaksudkan untuk menghasilkan pendidikan yang berkualitas sehingga peserta didik mampu bersaing dieranya di masa depan nanti. Berdasarkan uraian di atas maka penelitian yang dilakukan adalah penelitian yang dapat meningkatkan keterlibatan siswa dalam pembelajaran. Salah satu alternatif pemecahan masalahnya yaitu dengan penggunaan model pembelajaran inkuiri terbimbing.

Model pembelajaran inkuiri mengajak siswa untuk melakukan apa yang sedang dipelajari guna memenuhi rasa keingintahuan siswa itu sendiri (Sanjaya, 2009). Model inkuiri adalah rangkaian kegiatan pembelajaran yang menekankan pada proses berpikir secara kritis dan analitis untuk mencari dan menemukan sendiri jawaban dari suatu masalah yang dipertanyakan (Sanjaya, 2006). Hal ini sejalan dengan pendapat David L. Haury dalam artikelnya, Teaching Science Through Inquiry (1993) yang mengutip definisi dari Alferd Novak yakni inkuiri merupakan tingkah laku yang terlibat dalam usaha manusia untuk menjelaskan secara rasional fenomena yang sedang terjadi dan bertujuan untuk memancing rasa ingin tahu serta fokus pada pencarian pengetahuan atau pemahaman dalam hal memuaskan rasa ingin tahu (Dimyati dan Mudjiono, 2009). Gulo (2002) mengatakan bahwa inkuiri berarti suatu rangkaian kegiatan belajar yang mengakibatkan secara maksimal seluruh kemampuan siswa untuk mencari dan menyelidiki secara sistematis, kritis, logis, analitis, sehingga mereka dapat merumuskan sendiri penemuannya dengan penuh percaya diri (Trianto, 2007).

Model pembelajaran inkuiri terbimbing sendiri yaitu model inkuri dimana guru masih membimbing siswa melakukan kegiatan dengan memberi pertanyaan awal yang berfungsi mengarahkan awal jalannya diskusi di dalam kelas. Dalam inkuiri terbimbing kegiatan belajar harus dikelola dengan baik oleh guru atau pendidik. Inkuri jenis ini cocok untuk yang kegiatan belajar mengajar yang mendasar dalam satu bidang ilmu tertentu sebab pembelajaran dengan menggunakan model ini biasanya diperuntukkan untuk pembelajaran yang bersifat kontekstual (Trianto, 2008). Berdasarkan uraian tersebut maka dilaksanakan 
penelitian mengenai peningkatan hasil belajar kognitif produk Biologi materi ciriciri makhluk hidup dengan menerapkan model pembelajaran inkuiri terbimbing pada siswa kelas VII SMPN 3 Banjarbaru.

\section{METODE PENELITIAN}

\section{A. Subjek dan Lokasi Penelitian}

Subjek penelitian adalah siswa kelas VII SMPN 3 Banjarbaru yang berjumlah 25 Orang yang terdiri dari 11 orang perempuan dan 14 orang laki-laki. Lokasi penelitian berada di wilayah di SMPN 3 Banjarbaru Kecamatan Cempaka Kota Banjarbaru Provinsi Kalimantan Selatan. Pelaksanaan direncanakan pada semester genap tahun 2015/2016 selama 4 bulan yakni mulai bulan Maret sampai bulan Juni 2016.

\section{B. Jenis Penelitian}

Jenis penelitian ini menggunakan penelitian tindakan kelas (PTK). Menurut (Trianto, 2011) penelitian tindakan kelas lebih berorientasi pada penerapan tindakan dengan tujuan untuk peningkatan mutu atau pemecahan masalah pada sekelompok subyek yang sedang diteliti. Penelitian jenis ini juga dapat digunakan untuk mengamati tingkat keberhasilan akibat dari suatu tindakan KBM, untuk kemudian diberikan tindakan lanjutan yang bersifat penyempurnaan tindakan atau kegiatan penyesuaian sehingga diperoleh hasil yang lebih baik.

\section{Prosedur Pelaksanaan Penelitian}

Arikunto (2011) mengemukakan bahwa penelitian tindakan kelas (PTK) dilakukan dalam dua siklus dengan empat kali pertemuan (satu siklus terdiri dari dua pertemuan).

1. Siklus I

Prosedur penelitian tindakan untuk siklus I dapat dijabarkan sebagai berikut:

a. Perencanaan (Planning)

Tahap perencanaan persiapan tindakan (Planning) yang dilakukan dalam kegiatan ini adalah:

1) Menentukan tujuan pembelajaran

2) Membuat skenario pembelajaran melalui Rencana Pelaksanaan Pembelajaran (RPP) dan Lembar Kerja Siswa (LKS) untuk kegiatan diskusi

3) Menyusun intsrumen penelitian berupa prestes dan postes.

b. Pelaksanaan (Action)

Tahap pelaksanaan tindakan dilakukan dengan menggunakan inkuiri yang dilaksanakan dalam dua kali pertemuan pada saat pelaksanaan tindakan. Tahap kegiatan pembelajaran yaitu sebagai berikut:

1) Kegiatan awal yang meliputi memberikan motivasi dan menyampaikan tujuan pembelajaran

2) Melakukan pretest

3) Kegiatan inti yang meliputi pelaksanaan tindakan dari tahap-tahap model inkuiri terbimbing, sebelum itu dilakukan penginformasian 
singkat mengenai materi, pembagian kelompok siswa dan kemudian dilakukan tahapan model yaitu:

Fase 1 : Penyajian masalah

Fase 2 : Perumusan hipotesis

Fase 3 : Mengumpulkan data

Fase 4 : Menganalis data

Fase 5 : Membuat kesimpulan

4) Kegiatan akhir yang meliputi membimbing siswa menyimpulkan materi yang dipelajari

5) Melakukan postes

c. Observasi

Observasi dilakukan pada saat penelitian berlangsung dengan tujuan untuk melihat aktivitas siswa dan guru secara langsung dalam mengikuti serta melaksanakan proses belajar mengajar yang sesuai dengan RPP dibuat dengan menggunakan lembar observasi

d. Refleksi

Refleksi (Reflection) hasil yang diperoleh ada tahapan pengamatan dapat dikumpulkan dan di analisis sebagai bahan acuan untuk merefleksi dan melakukan perbaikan tindakan pada siklus pertemuan selanjutnya.

\section{Siklus II}

Prosedur pelaksanaan penelitian pada siklus II pada dasarnya sama dengan prosedur pelaksanaan penelitian pada siklus I. Perbedaannya adalah hanya pada materi yang disajikan merupakan kelanjutan dari materi di siklus I. Pelaksanaan tindakan siklus II mempertimbangkan hasil refleksi dari siklus I dan pada akhirnya kegiatan siklus II diberikan untuk mengetahui respon siswa terhadap pelaksanaan pembelajaran yang telah dilakukan.

\section{Teknik Pengumpulan Data}

Cara pengambilan data dalam Penelitian Tindakan Kelas ini dilakukan berdasarkan data hasil belajar siswa yang diambil dari nilai dari pretes dan postes.

\section{E. Teknik Analisis Data}

Analisis data yang digunakan dalam penelitian ini adalah analisis hasil belajar siswa yang diperoleh dari nilai pretes dan postes siswa, yang kemudian dianalisis dengan teknik ketuntasan belajar menggunakan persentase (\%). Nilai siswa dihitung dengan menggunakan rumus berikut.

$$
\text { Ketuntasan Individu }=\frac{\text { Nilai yang diperoleh }}{\text { Nilai maksimal }} \times 100 \%
$$

Berdasarkan jumlah siswa yang tuntas belajar, kemudian dihitung ketuntasan belajar secara klasikal. Ketuntasan belajar secara klasikal dihitung dengan menggunakan rumus berikut ini.

$$
\text { Ketuntasana Klasikal }=\frac{\text { Jumlah siswa yang tuntas belajar }}{\text { Jumlah seluruh siswa }} \times 100 \%
$$




\section{F. Indikator keberhasilan}

Indikator keberhasilan penelitian ini adalah apabila ditemukan adanya peningkatan hasil belajar siswa setelah proses pembelajaran berlangsung dan dapat mencapai KKM secara individu memperoleh nilai 70 atau secara klasikal apabila mencapai $85 \%$.

\section{A. Hasil}

\section{HASIL DAN PEMBAHASAN}

Hasil penelitian yang sudah dipaparkan sebelumnya dapat dibuat ringkasannya untuk memperoleh perbandingan antara hasil yang telah dicapai pada siklus I dan siklus II. Berdasarkan ringkasan data tersebut, dapat digunakan sebagai gambaran yang lebih jelas untuk hasil penelitian yang telah ada.

\section{Hasil Belajar Siswa Siklus 1}

a. Tes Hasil Belajar

Tes diberikan dalam bentuk pretes dan postes dengan hasil selengkapanya seperti pada Tabel 1 di bawah ini.

Tabel 1. Hasil Belajar Siswa Siklus 1

\begin{tabular}{|c|c|c|c|c|c|c|c|c|c|}
\hline \multirow{2}{*}{ No. } & \multirow{2}{*}{ Nama Siswa } & \multicolumn{4}{|c|}{ Pertemuan 1} & \multicolumn{4}{|c|}{ Pertemuan 2} \\
\hline & & Pretes & Ket & Postes & Ket & Pretes & Ket & Postes & Ket \\
\hline 1 & Adella Febrina & 50 & $*$ & 60 & $*$ & 70 & $* *$ & 90 & $* *$ \\
\hline 2 & Ameliya Putri & 50 & $*$ & 80 & $* *$ & 80 & $* *$ & 80 & $* *$ \\
\hline 3 & $\begin{array}{l}\text { Arrival Angger } \\
\text { Sakti }\end{array}$ & 50 & $*$ & 80 & $* *$ & 60 & $*$ & 80 & $* *$ \\
\hline 4 & $\begin{array}{l}\text { Chinta Adinda } \\
\text { Humaira }\end{array}$ & 70 & $* *$ & 100 & $* *$ & 70 & $* *$ & 100 & $* *$ \\
\hline 5 & $\begin{array}{l}\text { Denata Cristina } \\
\text { Silalahi }\end{array}$ & 60 & $*$ & 80 & $* *$ & 60 & $*$ & 70 & $* *$ \\
\hline 6 & Hamnah & 50 & $*$ & 60 & $*$ & 50 & $*$ & 80 & $* *$ \\
\hline 7 & $\begin{array}{l}\text { Husnul } \\
\text { Khatimah }\end{array}$ & 40 & $*$ & 80 & $* *$ & 40 & $*$ & 80 & $* *$ \\
\hline 8 & Ismi Aulia & 50 & $*$ & 60 & $* *$ & 50 & $*$ & 70 & $* *$ \\
\hline 9 & M. Naufal & 70 & $* *$ & 80 & $* *$ & 70 & $* *$ & 80 & $* *$ \\
\hline 10 & $\begin{array}{l}\text { Muhammad } \\
\text { Akmal F. }\end{array}$ & 70 & $* *$ & 100 & $* *$ & 70 & $* *$ & 100 & $* *$ \\
\hline 11 & $\begin{array}{l}\text { Muhammad } \\
\text { Fadillah F }\end{array}$ & 70 & $* *$ & 90 & $* *$ & 80 & $* *$ & 100 & $* *$ \\
\hline 12 & $\begin{array}{l}\text { Muhammad } \\
\text { Faturrahman }\end{array}$ & 60 & $*$ & 80 & $* *$ & 50 & $*$ & 80 & $* *$ \\
\hline 13 & $\begin{array}{l}\text { Muhammad } \\
\text { Imron }\end{array}$ & 70 & $* *$ & 80 & $* *$ & 50 & $*$ & 50 & $*$ \\
\hline 14 & $\begin{array}{l}\text { Muhammad } \\
\text { Rinto }\end{array}$ & 60 & $*$ & 80 & $* *$ & 50 & $*$ & 80 & $* *$ \\
\hline 15 & $\begin{array}{l}\text { Muhammad } \\
\text { Zainal Abidin }\end{array}$ & 20 & $*$ & 50 & $*$ & 50 & $*$ & 80 & $* *$ \\
\hline 16 & $\begin{array}{l}\text { Muhammad } \\
\text { Zaini }\end{array}$ & 60 & $*$ & 70 & $* *$ & 50 & $*$ & 80 & $* *$ \\
\hline
\end{tabular}




\begin{tabular}{|c|l|c|c|c|c|c|c|c|c|}
17 & Nur Sa'adah & 20 & $*$ & 50 & $*$ & 50 & $*$ & 50 & $*$ \\
\hline 18 & $\begin{array}{l}\text { Rahelius Deni } \\
\text { Malur }\end{array}$ & 40 & $*$ & 60 & $*$ & 40 & $*$ & 50 & $*$ \\
\hline 19 & Rahma Marisa & 60 & $*$ & 80 & $* *$ & 50 & $*$ & 80 & $* *$ \\
\hline 20 & $\begin{array}{l}\text { Rahmad } \\
\text { Saipudin }\end{array}$ & 30 & $*$ & 50 & $*$ & 40 & $*$ & 80 & $* *$ \\
\hline 21 & $\begin{array}{l}\text { Risky Dwi } \\
\text { Maulana N. }\end{array}$ & 70 & $* *$ & 90 & $* *$ & 70 & $* *$ & 100 & $* *$ \\
\hline 22 & Rizqa Saufiana & 50 & $*$ & 70 & $* *$ & 70 & $* *$ & 90 & $* *$ \\
\hline 23 & Suriadi & 60 & $*$ & 70 & $* *$ & 50 & $*$ & 50 & $*$ \\
\hline 24 & $\begin{array}{l}\text { Very Aji } \\
\text { Maulana }\end{array}$ & 30 & $*$ & 80 & $* *$ & 70 & $* *$ & 90 & $* *$ \\
\hline 25 & Vina Wahyuni & 40 & $*$ & 80 & $* *$ & 50 & $*$ & 90 & $* *$ \\
\hline \multicolumn{2}{|l|}{ Jumlah } & 1300 & & 1860 & & 1440 & & 1980 & \\
\hline \multicolumn{2}{|l|}{ Rata-rata nilai } & 52,00 & & 74,40 & & 57,60 & & 79,20 & \\
\hline Jumlah tuntas belajar & 6 & & 19 & & 9 & & 21 & \\
\hline \multicolumn{2}{|c|}{ Jumlah tidak tuntas } & 19 & & 6 & & 16 & & 4 & \\
\hline \multicolumn{2}{|l|}{ Ketuntasan klasikal } & $24,00 \%$ & $*$ & $76,00 \%$ & $* *$ & $36,00 \%$ & $*$ & $84,00 \%$ & $* *$ \\
\hline
\end{tabular}

$$
\begin{gathered}
\text { Keterangan } \\
* \quad \text { : Tidak Tuntas } \\
* * \quad \text { : Tuntas }
\end{gathered}
$$

Berdasarkan data Tabel 1 di atas dapat diketahui bahwa pada pertemuan 1 nilai rata-rata pretes adalah 52,00 dengan ketuntasan sebesar $24,00 \%$ dan nilai rata-rata postesnya adalah 74,40 dengan ketntasan klasikal sebesar 76,00\%. Pada pertemuan ke 2 nilai rata-rata pretes meningkat menjadi 57,60 dengan ketutasan klasikal sebesar $36,00 \%$. Nilai postesnya juga mengalami peningkatan menjadi sebesar $84,00 \%$. Berdasarkan ketuntasan klasikal yang tercapai sampai pada pelaksanaan postes pertemuan 2 tersebut, maka penelitian pada siklus I dikatakan belum berhasil karena ketuntasan yang tercapai masih dibawah batas minimal ketuntasan klasikal yang ditetapkan pada indikator keberhasilan penelitian ini, yakni sebesar $85 \%$.

\section{Hasil Belajar Siklus II}

a. Tes Hasil Belajar

Hasil belajar siswa melalui pemberian pretes dan postes pada pelaksanaan kegiatan pembelajaran siklus II dapat dilihat pada Tabel 2 di bawah ini.

Tabel 2. Hasil Belajar Siswa Siklus II

\begin{tabular}{|c|l|c|c|c|c|c|c|c|c|}
\hline \multirow{2}{*}{ No. } & \multirow{2}{*}{ Nama Siswa } & \multicolumn{4}{|c|}{ Pertemuan 1 } & \multicolumn{4}{c|}{ Pertemuan 2 } \\
\cline { 3 - 11 } & & Pretes & Ket & Postes & Ket & Pretes & Ket & Postes & Ket \\
\hline 1 & Adella Febrina & 70 & $* *$ & 70 & $* *$ & 70 & $* *$ & 70 & $* *$ \\
\hline 2 & Ameliya Putri & 60 & $*$ & 80 & $* *$ & 60 & $*$ & 80 & $* *$ \\
\hline 3 & $\begin{array}{l}\text { Arrival Angger } \\
\text { Sakti }\end{array}$ & 60 & $*$ & 70 & $* *$ & 60 & $*$ & 70 & $* *$ \\
\hline
\end{tabular}




\begin{tabular}{|c|c|c|c|c|c|c|c|c|c|}
\hline 4 & $\begin{array}{l}\text { Chinta Adinda } \\
\text { Humaira }\end{array}$ & 40 & $*$ & 80 & $* *$ & 70 & $* *$ & 80 & $* *$ \\
\hline 5 & \begin{tabular}{|l|} 
Denata Cristina \\
Silalahi
\end{tabular} & 50 & $*$ & 80 & $* *$ & 50 & $*$ & 80 & $* *$ \\
\hline 6 & Hamnah & 60 & $*$ & 80 & $* *$ & 70 & $* *$ & 80 & ** \\
\hline 7 & $\begin{array}{l}\text { Husnul } \\
\text { Khatimah }\end{array}$ & 70 & $* *$ & 80 & $* *$ & 70 & $* *$ & 80 & $* *$ \\
\hline 8 & Ismi Aulia & 60 & $*$ & 80 & $* *$ & 70 & $* *$ & 90 & ** \\
\hline 9 & M. Naufal & 70 & $* *$ & 90 & $* *$ & 70 & $* *$ & 100 & $* *$ \\
\hline 10 & $\begin{array}{l}\text { Muhammad } \\
\text { Akmal F. }\end{array}$ & 70 & $* *$ & 100 & $* *$ & 70 & $* *$ & 90 & $* *$ \\
\hline 11 & \begin{tabular}{|l} 
Muhammad \\
Fadillah F
\end{tabular} & 70 & $* *$ & 90 & $* *$ & 80 & $* *$ & 90 & $* *$ \\
\hline 12 & $\begin{array}{l}\text { Muhammad } \\
\text { Faturrahman } \\
\end{array}$ & 50 & $*$ & 90 & $* *$ & 50 & $*$ & 80 & $* *$ \\
\hline 13 & \begin{tabular}{|l|} 
Muhammad \\
Imron
\end{tabular} & 40 & $*$ & 60 & $*$ & 40 & $*$ & 50 & $*$ \\
\hline 14 & \begin{tabular}{|l} 
Muhammad \\
Rinto
\end{tabular} & 70 & $* *$ & 50 & $*$ & 70 & $* *$ & 90 & $* *$ \\
\hline 15 & \begin{tabular}{|l|} 
Muhammad \\
Zainal Abidin \\
\end{tabular} & 70 & $* *$ & 90 & $* *$ & 80 & $* *$ & 100 & $* *$ \\
\hline 16 & $\begin{array}{l}\text { Muhammad } \\
\text { Zaini }\end{array}$ & 70 & $* *$ & 100 & $* *$ & 80 & $* *$ & 100 & $* *$ \\
\hline 17 & Nur Sa'adah & 50 & $*$ & 100 & $* *$ & 50 & $*$ & 80 & $* *$ \\
\hline 18 & $\begin{array}{l}\text { Rahelius Deni } \\
\text { Malur }\end{array}$ & 70 & $* *$ & 50 & $*$ & 80 & $* *$ & 80 & $* *$ \\
\hline 19 & Rahma Marisa & 50 & $*$ & 80 & $* *$ & 50 & $*$ & 80 & $* *$ \\
\hline 20 & $\begin{array}{l}\text { Rahmad } \\
\text { Saipudin }\end{array}$ & 60 & $*$ & 80 & $* *$ & 60 & $*$ & 80 & $* *$ \\
\hline 21 & $\begin{array}{l}\text { Risky Dwi } \\
\text { Maulana N. }\end{array}$ & 40 & $*$ & 80 & $* *$ & 30 & $*$ & 80 & $* *$ \\
\hline 22 & Rizqa Saufiana & 70 & $* *$ & 80 & $* *$ & 70 & $* *$ & 90 & $* *$ \\
\hline 23 & Suriadi & 40 & $*$ & 90 & $* *$ & 50 & $*$ & 60 & $*$ \\
\hline 24 & $\begin{array}{l}\text { Very Aji } \\
\text { Maulana }\end{array}$ & 50 & $*$ & 60 & $*$ & 50 & $*$ & 80 & $* *$ \\
\hline 25 & Vina Wahyuni & 50 & $*$ & 80 & $* *$ & 50 & $*$ & 90 & $* *$ \\
\hline \multirow{2}{*}{\multicolumn{2}{|c|}{$\frac{\text { Jumlah }}{\text { Rata-rata nilai }}$}} & 1460 & & 1990 & & 1550 & & 2050 & \\
\hline & & 58,40 & & 79,60 & & 62,00 & & 82,00 & \\
\hline \multicolumn{2}{|c|}{ Jumlah tuntas belajar } & 10 & & 21 & & 13 & & 23 & \\
\hline \multicolumn{2}{|c|}{ Jumlah tidak tuntas } & 15 & & 4 & & 12 & & 2 & \\
\hline \multicolumn{2}{|c|}{ Ketuntasan klasikal } & $40,00 \%$ & $*$ & $84,00 \%$ & $* *$ & $52,00 \%$ & $*$ & $92,00 \%$ & $* *$ \\
\hline
\end{tabular}

Keterangan

* : Tidak Tuntas

** : Tuntas 
Berdasarkan data Tabel 2. di atas diketahui, pada pertemuan I nilai rata-rata pretes adalah 58,40 dengan ketuntasan klasikal sebesar 40,00\% dan nilai rata-rata postesnya adalah 79,60 dengan ketuntasan klasikalnya sebesar 84,00\%. Pada pertemuan 2 nilai rata-rata pretes meningkat menjadi 62,00 dengan ketuntasan klasikalnya sebesar 52,00\% dan nilai rata-rata postesnya adalah 82,00 dengan ketuntasan klasikal sebesar 92,00\%. Berdasarkan ketuntasan klasikal yang diperoleh sampai pada pelaksanaan postes pertemuan 2 tersebut, maka penelitian pada siklus II dikatakan berhasil karena ketuntasan yang telah ditetapkan pada indikator keberhasilan penelitian ini tercapai, yakni sebesar $85 \%$.

\section{Ringkasan Hasil Belajar Kognitif Produk Siswa}

Hasil belajar siswa yang diperoleh dari hasil pretes dan postes, secara keseluruhan dapat dilihat dari ketuntasan klasikal yang tercapai. Ringkasan hasil belajar siswa selama berlangsungnya penelitian siklus I dan siklus II dapat ditunjukkan pada Tabel 3 di bawah ini.

Tabel 3. Hasil Belajar Pada Siklus I dan Siklus II

\begin{tabular}{|c|c|c|c|c|}
\hline \multirow{2}{*}{$\begin{array}{l}\text { Ketuntasan } \\
\text { Klasikal }\end{array}$} & \multicolumn{2}{|c|}{ Siklus I } & \multicolumn{2}{c|}{ Siklus II } \\
\cline { 2 - 5 } & & Pertemuan & Pertemuan & Pertemuan \\
& Pertemuan 1 & 2 & 1 & 2 \\
\hline Pretes & $24,00 \%$ & $36,00 \%$ & $40,00 \%$ & $52,00 \%$ \\
\hline Postes & $76,00 \%$ & $84,00 \%$ & $84,00 \%$ & $92,00 \%$ \\
\hline
\end{tabular}

\section{B. Pembahasan}

Pembahasan atas hasil penelitian yang telah dilakukan terhadap siswa SMPN 3 Banjarbaru, pada pembelajaran konsep ciri-ciri makhluk hidup dengan menggunakan model pembelajaran inkuiri terbimbing adalah sebagai berikut.

1. Tes Hasil Belajar

a. Siklus I

Berdasarkan data hasil belajar siswa pada Tabel 1, dapat diketahui pada pertemuan 1 nilai rata-rata pretes adalah 52,00. Jumlah siswa yang tuntas belajar ada 6 orang dan yang tidak tuntas sebanyak 19 orang siswa sehingga ketuntasan klasikal yang tercapai adalah $24,00 \%$. Setelah berlangsung kegiatan pembelajaran dengan model inkuiri terbimbing nilai rata-rata postes adalah 74,40. Jumlah siswa yang tuntas belajar ada 19 orang dan yang tidak tuntas 6 orang siswa sehingga ketuntasan klasikal mencapai 76,00\%.

Hasil belajar pada pertemuan 2 menunjukkan nilai rata-rata pretes adalah 57,60. Jumlah siswa yang tuntas belajar ada 9 dan yang tidak tuntas 16 orang siswa sehingga ketuntasan klasikal yang tercapai adalah 36,00\%. Setelah berlangsung kegiatan pembelajaran dengan model inkuiri terbimbing nilai ratarata postes adalah 79,20. Jumlah siswa yang tuntas belajar ada 21 orang dan yang tidak tuntas hanya 4 orang siswa sehingga ketuntasan klasikal mencapai 84,00\%.

Banyaknya siswa yang tidak tuntas belajar pada saat pelaksanaan pretes baik pada pertemuan 1 maupun pertemuan 2 menunjukkan bahwa pengetahuan awal siswa tentang materi pelajaran yang disajikan masih sedikit. Setelah dilaksanakan kegiatan pembelajaran, hasil postes yang diberikan menunjukkan adanya peningkatan hasil belajar kognitif produk siswa. Hal tersebut menunjukkan bahwa pemahaman siswa terhadap materi pelajaran yang disajikan 
guru telah mengalami peningkatan. Peningkatan hasil belajar pada siklus I dimungkinkan karena melalui penggunaan model pembelajaran inkuiri terbimbing, ternyata siswa merasa lebih senang dan termotivasi dalam belajar.

Hasil belajar siswa yang tercapai pada siklus I sampai pada pertemuan 2 belum bisa dipakai sebagai dasar keberhasilan penelitian ini, karena ketuntasan klasikal yang tercapai pada pelaksanaan proses masih berada di bawah batas minimal ketuntasan yang telah ditetapkan yakni sebesar $85 \%$. Oleh karena itu hasil belajar tersebut dijadikan sebagai bahan pertimbangan peneliti untuk melanjutkan penelitian pada siklus II.

\section{b. Siklus II}

Hasil belajar siswa pada siklus II dapat dilihat pada Tabel 2. Berdasarkan data yang ada dapat diketahui bahwa pada pertemuan 1 nilai rata-rata pretes adalah 58,40. Jumlah siswa yang tuntas belajar ada 10 orang dan yang tidak tuntas sebanyak 15 orang siswa sehingga ketuntasan klasikal yang tercapai adalah $40,00 \%$. Setelah berlangsung kegiatan pembelajaran dengan model inkuiri terbimbing, nilai rata-rata postes adalah 79,60. Jumlah siswa yang tuntas belajar ada 21 orang dan yang tidak tuntas 4 orang siswa sehingga ketuntasan klasikal mencapai $84,00 \%$.

Hasil belajar pada pertemuan 2 menunjukkan nilai rata-rata pretes adalah 62,00 . Jumlah siswa yang tuntas belajar ada 13 orang dan yang tidak tuntas ada 12 orang sehingga ketuntasan klasikal yang tercapai adalah 52,00\%. Setelah berlangsung kegiatan pembelajaran dengan model inkuiri terbimbing nilai ratarata postes adalah 82,00 . Jumlah siswa yang tuntas belajar ada 23 orang dan yang tidak tuntas hanya ada 2 orang siswa sehingga ketuntasan klasikal mampu mencapai persentase sebesar $92,00 \%$.

Berdasarkan data di atas, hasil belajar siswa pada siklus II terlihat mengalami peningkatan. Peningkatan hasil belajar siswa pada siklus II, disebabkan karena siswa semakin memahami dan mampu beradaptasi dengan model pembelajaran yang dibawakan guru sehingga siswa tampak semakin senang dalam mengikuti kegiatan pembelajaran pada siklus II ini. Hal demikian juga terlihat dari banyaknya siswa yang terlibat secara aktif saat kegiatan pembelajaran sedang berlangsung.

Menurut Ahmadi dan Supriyono (2004) aktivitas siswa selama proses belajar mengajar merupakan salah satu indikator adanya keinginan siswa untuk belajar. Kegiatan-kegiatan yang dimaksud adalah kegiatan yang mengarah pada proses belajar seperti bertanya, berdiskusi, mengajukan pendapat dapat menjawab pertanyaan guru dan bisa bekerjasama dengan siswa lain. Kondisi pembelajaran yang demikian dapat menimbulkan semangat dan motivasi siswa dalam belajar sehingga siswa dapat belajar memahami materi pelajaran dengan lebih mudah.

Hasil yang dicapai pada penelitin ini, diperkuat dengan hasil penelitian dari Danar Anizar (2013). Hasil penelitiannya menunjukkan nilai rata-rata siklus I dan II berturut-turut sebesar 82 dan 88. Penelitian oleh Lodia Johanis (2014) juga menunjukkan gejala yang sama, dimana hasil belajar siswa sebelum dilakukan proses belajar mengajar (PBM), sebanyak 31 siswa hasil belajarnya tidak tuntas atau mendapatkan nilai di bawah KKM.

Berdasarkan ketuntasan klasikal yang tercapai pada siklus II, maka penelitian yang dilakukan pada siklus II ini bisa dikatakan berhasil. Hal ini karena secara klasikal siswa sudah tuntas dalam belajar, yakni mencapai ketuntasan 
92,00\% bahkan ketuntasan klasikal tersebut telah melebihi batas ketuntasan klasikal yang diharapkan, yakni sebesar $85 \%$. Dengan demikian dapat dikatakan, melalui penggunaan model pembelajaran inkuiri terbimbing, terbukti dapat meningkatkan hasil belajar kognitif produk siswa pada materi biologi konsep ciriciri makhluk hidup.

\section{KESIMPULAN}

Berdasarkan hasil penelitian dan pembahsan yang telah dilakukan, maka dapat diambil kesimpulan sebagai berikut: Hasil belajar siswa pada konsep ciriciri makhluk hidup dapat ditingkatkan melalui penggunaan model inkuiri terbimbing dari tidak tuntas belajar secara klasikal $(84,00 \%)$ pada siklus I menjadi tuntas $(92,00 \%)$ pada siklus II. Peningkatan hasil belajar siswa pada siklus II, disebabkan karena siswa semakin memahami dan mampu beradaptasi dengan model pembelajaran yang dibawakan guru sehingga siswa tampak semakin senang dalam mengikuti kegiatan pembelajaran pada siklus II ini.

\section{DAFTAR PUSTAKA}

Ahmadi, Abu dan Supriyono Widodo, 2004. Psikologi Belajar. Jakarta: PT Rineka Cipta.

Arikunto, Suharsimi. 2011. Prosedur Penelitian Suatu Pendekatan Praktek. Rineka Cipta. Jakarta.

A. M. Sardiman, 2000. Interaksi dan Motivasi Belajar Mengajar. Jakarta: PT Raja Grafindo Persada.

A.M. Sardiman. 2011. Interaksi dan Motivasi Belajar Mengajar. PT Rajagrafindo. Jakarta.

Carin, A. A. and Sund, R. B., (1975). Teaching Science Thorgh Discovery. Thir Editional Charles Merril Publishing Company. Colombus, Ohio.

Anizar, Danar. 2013. Penerapan Pembelajaran Inkuiri Terbimbing Terhadap Minat dan Hasil Belajar Biologi Siswa Kelas VII 2 SMPN 34 Pekanbaru Tahun Ajaran 2013/2014. Pekanbaru: Universitas Islam Riau.

Dalyono. 2005. Psikologi Pendidikan. Jakarta: Rineka Cipta.

Darsono dkk. 2000. Belajar dan Pembelajaran. Semarang: IKIP Semarang Press.

Depdiknas. 2005. Ilmu Pengetahuan Alam (Aplikasi Karakteristik Peserta Dididk dalam Pembelajaran Ilmu Pengetahuan Alam). Jakarta: Departemen Pendidikan Nasional Direktorat Jenderal Pendidikan Dasar dan Menengah Direktorat Pendidikan Lanjutan Pertama. 
Dimyati dan Mudjiono. 2009. Belajar dan Pembelajaran. Jakarta: Rineka Cipta.

Gulo, W. 2002. StrategiBelajarMengajar Jakarta: Grasindo.

Johanis, Lodia. 2014. Penerapan Strategi Guided Inquiry Untuk Meningkatkan Hasil Belajar Siswa Ambon Konsep Sistem Pernapasan Manusia Kelas XI SMA Negeri 12 Ambon. Ambon: Universitas Ambon.

Sanjaya, Wina. 2006. Strategi Pembelajaran Berorientasi Standar Proses Pendidikan. Jakarta: Kencana Prenada Media Group.

Sanjaya, Wina. 2009. Kurikulum dan Pembelajaran. Jakarta: Kencana Prenada Media Group.

Trianto. 2007. Model-model Pembelajaran Inovatif Berorientasi Konstruktivisti Konsep Landasan Teoritis Praktis dan Implementasinya. Jakarta: Prestasi Pusaka.

Trianto. 2008. Mendesain Model Pembelajaran Konstektual. Jakarta: Cerdas Pustaka.

Trianto. 2011. Model-model Pembelajaran Inovatif Berorientasi Konstruktivistik: Konsep, Landasan Teoritis-Praktis dan Implementasinya. Jakarta. Prestasi Pustaka. 